\title{
Living a Multicultural Lifestyle with Batik: Identity, Representation, Significance
}

\author{
Awalia Rahma \\ Dept. of Islamic History and \\ Civilization \\ Faculty of Adab and Humanities \\ Syarif Hidayatullah State Islamic \\ University \\ Jakarta, Indonesia \\ awalia.rahma@uinjkt.ac.id
}

\author{
Jejen Jaenudin \\ Dept. of Educational Management \\ Faculty of Tarbiyah and Educational \\ Sciences \\ Syarif Hidayatullah State Islamic \\ University \\ Jakarta, Indonesia \\ jejen.jaenudin@uinjkt.ac.id
}

\author{
Alfida Marifatullah \\ Dept. of Islamic History and \\ Civilization \\ Faculty of Adab and Humanities \\ Syarif Hidayatullah State Islamic \\ University \\ Jakarta, Indonesia \\ alfidamarifatullah@mhs.uinj \\ kt.ac.id
}

\begin{abstract}
This study discusses north coast Java batik as part of everyday lifestyle. The north coast Java (Pesisir) batik signifies multi culture and beauty as compared to Court batik with its philosophical meanings. Studies focusing on lifestyle as part of consumption have not been widely written. The use of batik then raises a question: How do people live their multicultural lifestyle with batik? This ethno-history study sees different civilizations and religions made important contributions in terms of motifs, colors, producers and consumers in four batik loci (Cirebon, Pekalongan, Batang and Lasem). Local climate, government's policy and UNESCO's acknowledgement also becomes important factors for multicultural lifestyle formation. The consumption of batik, however, shows users' fluid identity; after people's taste and preference.
\end{abstract}

Keywords- Batik; north coast; Java; lifestyle; multi culture

\section{INTRODUCTION}

Since the second half of the $19^{\text {th }}$ century, batik has shown its user identity due to the development of complex visual language, with special colors and motifs narrating social status, age, ethnicity and region, marital status, age and the occasion of batik use. Then, the Javanese, Sundanese, Chinese, Arabs and Eurasians wear batik according to their ethnic/racial character [1].

The mainstream Javanese batik, originated from Kraton (court) of Yogyakarta and Surakarta (vorstenlanden) was challenged by the more dynamic counterpart in terms of colors, motifs and philosophical values of north coastal batik. Coastal Batik refers to batik developed on the north coastal Java such as Cirebon, Pekalongan, Semarang, and Lasem. Coastal Batik demonstrates more freedom of expression in batik making out of more Kraton values. This type of batik originated from the idea of Eurasians or Chinese Peranakans who Created flower bouquet or European motifs such as Cinderella and Red Riding Hood into their sarongs [1].
In short, many cultures and religions influenced batik development since the Dutch era, which includes European culture, China, Arab, India, Japan, Java, Islam, Buddhism and others. Cultural diversity is not only happening at the motifs level, but also includes various values recorded in colors that represent many cultures.

\section{METHOD}

The study of batik is approached by ethno-history. Batik as daily articles (material culture) will certainly occupy the portion as an explanatory chapter for the whole research that will be more discussed on how batik is used in everyday life. The research generates interviews which are conducted with manufacturers, experts, users, collectors, batik curators in four cities; Cirebon, Pekalongan, Batang, and Lasem. All the four cities represent the traditions of Pesisir (coastal batik). The results of the interviews in the four cities will be an interesting comparison of how the cities with their distinctive characters affect the lifestyle of batik people around, and even out of the region to abroad.

This research also employs lifestyle history, especially ordinary or everyday lifestyle theories from Bell and Hollows [2], a kind of everyday lifestyle that not only discusses lifestyle "elite class" but also penetrates into the ordinary lifestyle that is not related to a particular class. Ordinary lifestyle clarifies the identity of certain groups or races. Bell and Hollows lifestyle theory will be combined with the Trentmann consumption theory to get a complete picture of batik usage as a category of analysis. Trentmann sees that any society engages in consumption by buying, exchanging, giving, or using objects and services. But it was not until the nineteenth and twentieth centuries that consumption practices had been associated with identity, audience, or a category of analysis [3]. 


\section{RESULT AND DISCUSSION}

That batik today portrays multiculturalisis recognized by various groups such as batik businessman from Lasem, Sigit Witjaksono and Widiati Widjaja (Chinese Peranakan), also batik entrepreneur and maker from Cirebon Uka (Cirebonese), the daughter of the late batik maestro Masina, and batik maestro Katura also from Cirebon. Witjaksono adds Chinese characters in his batik cloth, intentionally to confirm his multicultural identity. Referring to some Chinese sayings, his batiks attract even greater customers, not only from Chinese Peranakans, but also Javanese. Rahardi Ramelan, a collector and batik enthusiast has a different opinion. Concerning multicultural motif such as Hong Bird (phoenix), Ramelan's comment shows a paradox. On the one hand, his argument tends to deny it, arguing that batik is only a matter of making process. But when he was asked about phoenix bird motifs as an influence of Chinese culture, he argued that it is the implications of its Chinese producers. He added that it is natural that they (producers) actualize their cultural values on batik motifs [4] When Widianti Lian, the third generation of Oey Soe Tjoen, was asked about Hokokai motif, she argued that what actually happened during Japanese colonialization was that people experienced economic difficulties, the economy was very sluggish. Therefore, batik was given great-detailed fillings (isen-isen) and motifes so that the batik makers could finish their long cloth (kain panjang) longer in terms of time. This would avoid their precious batiks to be changed with only three pieces of cloths. Peranakan Batiks she makes are not meant to be multicultural, yet they are meant to target upper class with soft colors and high quality as her grandparents demanded to meet with the Oey Soe Tjoen batikkerij quality [5].

Another multicultural motif was jlamprang (nitik) which is popular in Pekalongan. This geometrical batik was a negotiation of Islamic value practiced by some Arabs of Pekalongan and Indian patola motif. Islam found that the geometrical shape in batik was clearly safe for them theologically instead of animate figures as generally written in Pekalongan's Dutch and Chinese influenced batiks [6] [7]. This also happens to the Rifaiyah tarika in Batang when they cut off animal's head on their batik cloths [8].

Certain motifs of batik made one of Javanese ritual equipment. These motifs may function as tolak bala, head scarf for bride in wedding ceremony, healing and as a marker for haunted sites.[9] North coast batik for offering purpose in Pekalongan is jlamprang. It is exclusively offered to Dewi Lanjar, goddess of the north coast of Java [10]. Ramelan confirms this motif was made for ritual in the first place [11].

Various ethnic groups of Batik consumers can be divided into two categories: pragmatic consumers and ideological consumers. The first category of consumers are those who view the function of batik clothing as a fashion, outside its main function as body covering, which is for some is the actual daily function. The second category of consumers, the ideological consumers, are those who not only wear batik functionally, but also consider the halal aspect of the basic material of batik and its motives from the point of view of Islamic law. In this case, these particular ideological consumers come from a group of Javanese santri and Arab ethnic groups. It is ideological for both groups to avoid the basic materials of silk and batik motifs of living creatures because these will clash with the provisions of Islamic Shari'a.

Outside the interchanging of batik with the teachings of Islamic sharia, batik has become the daily clothing of the Javanese population particularly after the hand-print technology appeared in the batik industry at the end of the $19^{\text {th }}$ century so that batik prices become more affordable [12].

That batik is an identity for many, there is no doubt about it. From the interviews of many groups such as museum curators, batik experts, collectors, batik enthusiasts, producers and users of batik the point is clearly confirmed. Identity is represented is diverse ranging from social class, ethnicity, religion, etc. In the social class context, batik is used by particular social groups as an expression of social status such as those of Chinese Peranakans, or those of religious tarika groups in Batang called the Rifaiyah. In the past, batik encim used by Chinese Peranakan as their social class statement and age, now batik encim can be used by anyone regardless of their ethnicity and age. The expression of social class in batik at the present time is more determined by the complexity and fineness in batik making which then have implications for its price. A fine batik can cost tens of millions of rupiah in which only people with certain economic classes can afford it. This, to some extent, justifies Wronska-Friend's analysis that there was a shift in which Batik, once used by certain elite groups with the aim of reflecting socioeconomic identity, is now used widely by ordinary people regardless of their social and economic status. However, this argument is not entirely true due to the fact that the definition of batik itself according to its activists refers only to batik made through hand writing and stamp. They are only used by certain people who understand the definition of batik and represent a certain identity, that represent socioeconomic, as well as custom and religious values.

With different kind of fabric delicacy, motifs and colors, batik producers make different pricing which in turn segmented their customers. However, people can afford their chosen batik according to their preference and taste. Here customer's identity cannot be classified by ethnic, religion or social class.

This was in contrast with Indonesia during the colonial era when The Dutch East Indies in 1872 divided people into three classes of citizenship where they should wear their attributes according to their class [7]. The first class comprised of Europeans and Eurasians; second class were the Foreigner Easterners and the third class was constituted of the ordinary people of Indonesian origin. As a negotiation with tropical climate, batik made of cotton is suitable to be worn widely, as compare to silk from Chinese influence. The three classes freely wear batik for various purposes; sarong, long cloth, pants, handkerchief, interior, etc. Europeans usually wear bouquette of flowers with soft color or 
European-inspired folklore for their sarong; Chinese tend to identify themselves as Europeans while some others remain with Chinese-Buddhism influenced motifs.

Until now, batik is widely used today as part of the lifestyle. Our visit to several batik exhibitions shows that various circles of society irrespective of their ethnicity wear batik in their own styles, whether as clothes, pants, skirts, sarongs, headbands, shoes, sandals, bags, interior designs and so forth.

With UNESCO's acknowledgment to Indonesian batik as the Representative List of the Intangible Cultural Heritage of Humanity on October 2, 2009, Indonesian people are again proud of their multicultural identity. The massive use of batik motifs on cloth by the society has also not rigidly represented the culture or character of certain ethnic groups, except limited to those who have a better understanding of batik. It has been previously mentioned that Javanese, Sundanese, Indo-Chinese, Arabs and Indo- European descents wear batik according to their ethnic/racial character. In fact, the wider community uses batik with no profound understanding and is more concerned with motives than the meaning behind the motive itself which may represent more cultural or religious values.

Coastal batik expresses not only more freedom in creating new motifs, but also it expresses more cross- cultural motifs. In other words, coastal batik is batik for everybody regardless of their social, political, economic, cultural, ethnical and religious status. It is the batik from the ordinary people for all the people in Indonesia.

\section{CONCLUSION}

Coastal batik (Batik Pesisir) provides more freedom and alternative expression of batik. It symbolizes multiculturalism; it is not merely concerning industry but also philosophical values embedded on the artistic cloths. Different religious and ethnic groups made their significant contributions to batik's motifs, color and values.

During the colonial era, batik became popular as an ethnic identity in the public sphere, following Dutch Indies' policy on civil classification. Later the class identity in batik emerged as results of economic and feudalism. However, the consumption of batik shows users' fluid identity; after people's tastes and preferences.

This study shows local climate, government's policy and UNESCO's acknowledgement also became important factors for multicultural lifestyle formation.

\section{REFERENCES}

[1] M. Wronska-Friend, Batik Jawa bagi Dunia=Javanese Batik to the World. Jakarta: Komunitas Lintas Budaya Indonesia=Indonesian Cross-Cultural Community, 2016.

[2] D. Bell and J.Hollows, Eds., "Towards a History of Lifestyle," in Historicizing Lifestyle, Mediating Taste, Consumption and Identity from the 1900s to 1970 s, Hampshire: Ashgate, 2006, pp. 1-20.
[3] F. Trentmann, Ed., The Making of the Consumer: Knowledge, Power and Identity in the Modern World. Oxford: Berg, 2006.

[4] R. Ramelan, "Jakarta," 24-Aug-2017.

[5] W. Lian, "Kedungwuni Pekalongan," 28-Sep-2017.

[6] Harmen C. Veldhuisen, Batik Belanda 1840-1940: Pengaruh Belanda pada Batik dari Jawa Sejarah dan Kisah-kisah di sekitarnya. Jakarta: Gaya Favorit Press, 2007.

[7] J. K. Achjadi and A. Damais, Butterflies and Phoenixes: Chinese Inspirations in Indonesian Textile Arts. Jakarta: Mitra Museum Indonesia, 2005.

[8] Miftahutin, "Batang," 27-Sep-2017.

[9] F. Kerlogue, The Book of Batik: selections from the Rudolf G. Smend Collection. Singapore: Archipelago Press, 2004.

[10] G. R. Smend, "Javanese Batik the art of wax design," in Batik The Rudolf G. Smend Collection, Hongkong: Periplus, 2004.

[11] T. Ramelan, The 20th Century Batik Masterpieces. KR Communications, 2010.

[12] J. G. Taylor, "Identity, nation and Islam," IIAS Newsletter, p. 12, Winter-2008. 